\title{
Thyroid swellings- A Common Problem in Hilly Areas
}

\author{
Dr Shenny Bhatia, Dr Sumeet Mahajan, Dr Manpreet kaur \\ Dr. Parul Kansal \\ Deptt of otolaryngologyy,MMMCH, Solan.
}

\begin{abstract}
This study was conducted in MM Medical College, Solan on 60 patients of neck swelling who presented in Department of ENT. The aim of the study was to know the prevalence and frequency of various types of thyroid swellings and also to know the age and sex distribution of thyroid swellings. In this study, it was seen that out of 60 neck swellings, thyroid swellings were commonest -25(41.6\%) in number followed by lymph nodes, tubercular and sialadenitis. Out of thyroid swellings, female to male ratio was 3.2:1.
\end{abstract}

Key words: Goitre, FNAC, T3,T4,TSH, Neck swelling, USG

\section{Introduction}

Thyroid swellings consisting of colloid goitre,thyroiditis or neoplasia were evaluated in hilly area among neck swellings. Incidence of goitre (diffuse or nodular) is very much dependent on status of iodine intake of population. In areas of iodine deficiency, goitre prevalence is very high and it is seen that in goitre of long standing duration ,multinodularity develops frequently.

Enlargement of thyroid gland is the common manifestation of the IDD and goitre prevalence survey is used as diagnostic tool for identifying areas of IDD. Failure to undertake early detection and intervention measure results in secondary disabling conditions.Persons with goitre seek medical attention for many reasons, most commonly due to lump in the neck or growth spurt seen in a goitre known to be present for long time. Sometimes an increase in the size of lump causes pressure symptoms like difficulty in swallowing, cough, respiratorydistress and rarely recurrent laryngeal nerve palsy. Patient may also seek medical attention because of cardiac irregularities or congestive cardiac failure. ${ }^{1}$

Choice to investigate the functional state of patient with thyroid swelling may differ in different geographical areas. Most of the experts however perform serum $\mathrm{T}_{3} \mathrm{~T}_{4}$ and TSH assays.TSH is the most sensitive and at times ,the choice of investigation is free $\mathrm{T}_{4}$ and TSH.

FNAC is the procedure which provides material for definite cytological diagnosis without the disadvantages of open surgical biopsy.Aspiration cytology because of its simplicity,early availability of result,minimal trauma and minimal chances of dissemination is now considered a valuable diagnostic tool for benign neck lesions,lymphomas and metastatic carcinoma ${ }^{2}$.FNAC is of particular relevance in head and neck region because of easy accessibility of target sites. In the hands of a skilled cytologist, accuracy exceeds with a few false negative and very occasional a false positive report ${ }^{2}$. FNA Cytology is a widely utilized tool for the diagnosis of thyroid lesions with high degree of sensitivity, specificity and diagnostic accuracy. ${ }^{3}$ Ultrasonography(USG) has been used frequently because of low cost,limited discomfort to patient and nonionizing nature of method .It may detect non-palpable nodule or goitre ,monitor the changes following therapy and guide FNAC.The major strength of CT/MRI is the ability to diagnose and assess extent of substernal goitre.As CT is the source of ionizing radiation so its use in imaging method should be reserved for intra thoracic multinodular goitre with tracheal compression.

\section{Aims And Objectives}

To study the prevalence of thyroid swelling in hilly area of district Solan, to know the frequency of occurrence of various thyroid swelling and to know the age and sex distribution of thyroid swelling.

\section{Material And Methods}

This prospective study was conducted on 60 patients upto 60 years of age who presented with neck swellings in the department of ENT,M.M.Medical College and Hospital,District Solan for a period of 6 months from $1^{\text {st }}$ July,2013 to 31st December,2013.

All patients were evaluated by thorough clinical history,complete detailed examination followed by routine investigation. FNAC and USG Neck was carried out in all 60 patients. Other investigations like thyroid hormone assays,CT/MRI were done wherever necessary.

Patients with cystic swellings like cystic hygroma,branchialcyst,hemangiomas,sinuses,fistulas,traumatic and inflammatory swellings were excluded from this study. 


\section{Results}

Out of 60 patients with neck swellings,25(41.6\%) were thyroid swellings, $16(26.6 \%)$ were reactive lymph nodes , 10(16.6\%) were tubercular,7 (11.6\%) patients were of submandibular sialadenitis and $2(3.3 \%)$ were neck swellings with unknown primary.

Table 1- Types of neck swelling

\begin{tabular}{|l|l|l|}
\hline Type of Neck Swelling & Number & Percentage(\%) \\
\hline Thyroid Swellings & 25 & 41.6 \\
\hline Reactive lymph nodes & 16 & 26.6 \\
\hline Tubercular Pathology & 10 & 16.6 \\
\hline Submandibular Sialadenitis & 7 & 11.6 \\
\hline Neck swelling with unknown primary & 2 & 3.3 \\
& & \\
\hline
\end{tabular}

TABLE 2- Types of thyroid swellings

\begin{tabular}{|l|l|l|l|}
\hline Type of thyroid swelling & Number & Percentage(\%) & Thyroid status \\
\hline Colloid goitre & $16 ; 12$-simple,4-multinodular & 64 & $\begin{array}{l}11 \text {-Euthyroid,4- } \\
\text { hypothyroidism }\end{array}$ \\
\hline Thyroiditis & 5 & 20 & $\begin{array}{l}\text { Hyperthyroid-2 } \\
\text { Hypothyroid-1 } \\
\text { Euthyroid-2 }\end{array}$ \\
\hline Neoplastic & & & Euthyroid \\
& $\begin{array}{l}\text { 2-papillary neoplasm } \\
\text { 2-follicular neoplasm }\end{array}$ & 16 & \\
\hline
\end{tabular}

Out of 25 thyroid swellings, 16 cases were of colloid goitre(64\%).Out of 16 cases, 12(75\%) were of simple diffuse goitre and $4(25 \%)$ were of multinodular goitre.5 cases $(20 \%)$ were of thyroiditis and 4 cases $(16 \%)$ were neoplastic. Out of these, 2 were of follicular neoplasia. Maximum cases i.e. 17(68\%) were euthyroid.

Table 3- Age distribution of thyroid swelling

\begin{tabular}{|l|l|}
\hline Type of thyroid swelling & Age distribution(in years) \\
\hline Colloid goitre & $10-36$ \\
\hline Thyroiditis & $30-40$ \\
\hline Neoplastic & $44-60$ \\
\hline
\end{tabular}

Thyroid swellings were common in age group of 10-60 years. Out of these, majority of the thyroid swellings(colloid goitre) were seen between 10-36 years of age.

Table 4- Sex distribution of various thyroid swellings

\begin{tabular}{|l|l|l|l|l|l|}
\hline $\begin{array}{l}\text { Type of thyroid } \\
\text { Swellings }\end{array}$ & Number & Male & Percentage(\%) & Female & Percentage(\%) \\
\hline Colloid goitre & 16 & 4 & 25 & 12 & 75 \\
\hline Thyroiditis & 5 & - & & 5 & 100 \\
\hline Neoplastic & 4 & 2 & 50 & 2 & 50 \\
\hline Total & 25 & 6 & 24 & 19 & 76 \\
\hline
\end{tabular}

Out of 25 thyroid swellings, 19 were females(76\%) and $6(24 \%)$ were males.

\section{Discussion}

The most common contributing factor of thyroid swellings in hilly area are iodine deficiency and dietary habits.It is seen in hilly areas that consumption of naturally occurring goitrogens like soyabean,cassava,millets, sorghum,sweetpotato,broccoli,cabbage and cauliflower lead to thyroid disorders. Iodine is usually leached away by erosion in soil in mountainous area.

\section{Prevalence}

In the present study, out of 60 neck swellings, thyroid swellings formed the largest group accounting for $25(41.6 \%)$ cases followed by reactive lymph nodes (16 cases, 26.6\%), submandibular sialadenitis(7,11.6\%), tubercular(10,16.6\%) and neck swelling with unknown primary(2,3.3\%).

Among 25 thyroid swellings, colloid goitre was the most common forming 16(64\%) followed by thyroiditis forming 5(20\%) and neoplastic lesions forming 4(16\%) cases. 
The prevalence and frequency of thyroid lesions was in accordance with the study done by V.Popat et al (2009) ${ }^{4}$ which showed the clinicopathological correlation of neck lesions on 103 cases and reported thyroid lesions as maximum number(31.06\%) followed by throat lymph node(20.38\%), skin and soft tissues of neck $(18.44 \%)$ and salivary gland $(6.79 \%)$ in decreasing order of frequency. Out of 32 thyroid swellings, goitre was commonest,diffuse and multinodular constituted highest percentage i.e. $24 \%$.

Our study was not in accordance with the study done by U.Jindal et al(2012) ${ }^{5}$ (Spectrum of head and neck swellings in rural population of Indiabased on FNAC on 350 cases. In this study, lymph node enlargement was the commonest $(50.85 \%)$ followed by thyroid lesions $(22.85 \%)$ and salivary gland swellings $(8.5 \%)$.

Our study was also in accordance with study done by W.Ergete et al(2003) ${ }^{6}$ (Histopathological pattern of thyroid disease) where prevalence was $18-30 \%$ and nodular colloid goitre was most prevalent.

\section{Age distribution:}

Age of presentation for neck swellings in our study varied from 6-60 years of age and for thyroid swellings varied from 14-55 years .Our study was in accordance with study done by R.Mansoor(2010) ${ }^{7}$ where maximum patients out of 139 cases fell in 16 - 40 years of age. It is also in accordance with study done by U.Jindal et al $(2012)^{5}$-Spectrum of head and neck swelling in rural population of India based on FNAC where age of presentation varied from 1-85 years.

\section{Sex distribution:}

In our study,females predominated over males with male to female ratio of 1:3.2. Our study was in accordance with study done by R.S.Patil et al $(2013)^{8}$ where male to female ratio was $1: 1.58$. Our study was also in accordance with the studies conducted by B.Tsegaye et al $(2003)^{6}$, R.Mansoor $(2010)^{7}$ where male to female ratio was 1:4.13 and 1:5.8 respectively.

\section{Conclusion}

The present study was done on 60 cases under 60 years of age who presented with neck swellings in the ENT Department of M.M.Medical College and Hospital, Solan from July 2013 to December 2013.

All the 60 patients were subjected to detailed history,clinicalexamination,FNAC and USG neck.Other investigations like $\mathrm{T}_{3}, \mathrm{~T}_{4}$, TSH,X-Ray soft tissue neck,CT/MRI were done wherever required.

In the present study,majority of the swellings were thyroid swellings i.e $41.6 \%$ and out of which majority (64\%) were of colloid goitre.

Majority of patients of thyroid swellings(41.6\%) were in age group of 20-45 years of age and females predominated over males.

\section{Bibliography}

[1]. Kamath, Vinod Bhat,RSP Rao,Acharya Das,Ganesh K.S and AshaKamat.Prevalence of goitre in rural area of Belgaum District of Karnatka.Indian Journal of Community Med 2009, Jan 34(1);48-51.

[2]. M Aslam, SM Hasan and SA Hasan.Fine needle aspiration cytology versus histopathology in cervical lymphadenopathy. Ind. J. Otolaryngo/Head Neck Sug.Apr 2000.52(2)

[3]. I.V Renuke, G.SailaBala,C.Aparna,K.Sumanlatha.The Bethesda system for reporting thyroid cytopathology.Interpretation and guidelines in surgical treatment.IJOHNS Oct-Dec 2012,64(40;305-311.

[4]. V.Popat, D Vora, H Stal.Clincopathological correlation of neck lesions. A study of 103 cases. The internet journal of head and neck surgery.2009; Vol 4; number2

[5]. U Jindal, K Singh, A Baghla, A Kochar.Spectrum of head and neckswellings in the rural population of India based on Fine needle aspiration findings. The Internet journal of Head and neck surg.2012; vol5;number 2

[6]. B.Tsegaye and W.Ergete.histopathological pattern of thyroid disease:East African Medical Journal.Vol No.10,oct 2003.

[7]. R.Mansoor:Spectrum of thyroid disease,An experience in the tertiary care and teaching hospital.Am.Pak.Inst.MedSci 2010,5(2),101-106.

[8]. Rajesh S.Patil,Naren V Nimbal,PratimaS,SowyeR.Patil,Sreekanth and Ramiya:Histopathological study of thyroid lesions.Int.J.PharmaBioSc 2013 Oct 4(4);1003-1020 